\title{
PENGARUH PEMUPUKAN DAN PEMANGKASAN TANAMAN TERHADAP PRODUKTIVITAS DAUN MURBEI DI KOTA TOMOHON, SULAWESI UTARA
}

The effect of fertilization and trimming on the productivity of mulberry leaves in Tomohon City, North Sulawesi

\author{
Lis Nurrani ${ }^{1}$, Supratman Tabba ${ }^{1}$ dan Andi Wildah ${ }^{1}$ \\ ${ }^{1}$ Kontributor Utama Balai Penelitian dan Pengembangan Lingkungan Hidup dan Kehutanan Manado \\ Jl. Raya Adipura Kel. Kima Atas Kec. Mapanget Kota Manado, Sulawesi Utara \\ email penulis korespondensi: lisnurrani@gmail.com
}

Tanggal diterima: 15 Agustus 2019, Tanggal direvisi:19 Agustus 2019, Disetujui terbit : 02 Desember 2019

\begin{abstract}
Mulberry is remain the only important feed determined the productivity of cocoons on silkworm cultivation. Development of hybrid mulberry that contain high nutrition is very important because their nutritional value is the most influences key factor toward the quality and quantity of cocoons and silk. This study aimed to determine the effect of fertilization and trimming on the leaves productivity of three species of mulberry in a demonstration plot in Rurukan village, Tomohon city, North Sulawesi. This study used a completely randomized design with a factorial research design of three species of mulberry leaves (SULI 01, M.cathayana dan M.kanva) with three types of fertilizer (Taikam, Petroganik dan Kandang) to determine the effect of fertilizing. Two species of mulberry (M.cathayana dan M.kanva) with three different trimming heights $(30 \mathrm{~cm} .45 \mathrm{~cm}$ dan $60 \mathrm{~cm}$ from the ground) to determine the effect of trimming techniques. The source of mulberry genetic material comes from The Forest Productivity Research and Development Center in Bogor. The parameters measured include diameter growth, height and leaves production. The results showed that in general the fertilization aplication had no effect on leaves productivity in all species of mulberry tested. Application of Taikam fertilizer and manure only affects the growth of diameter and height of mulberry plant. The trimming treatment has an influence on leaves productivity. The highest leaf production resulted by M.kanva (639.61 gr) on high trimming $45 \mathrm{~cm}$, on the other side the highest leaf production of M.cathayana on high trimming $60 \mathrm{~cm}$ from the ground (482.40 gr).
\end{abstract}

Keywords: SULI 01, fertilizer, M.cathayana, M.kanva, fertilizer, growth, leaves weight

\begin{abstract}
ABSTRAK
Hingga saat ini murbei masih menjadi satu-satunya pakan penting yang menentukan produktivitas kokon dalam budidaya serikultur ulat sutera. Pengembangan murbei unggul, khususnya jenis hibrid, yang mengandung nutrisi tinggi sangat penting dilakukan mengingat nilai gizi murbei merupakan faktor kunci yang paling berpengaruh terhadap kualitas dan kuantitas kokon dan benang sutera. Tujuan dari penelitian ini adalah untuk mengetahui pengaruh pemupukan dan pemangkasan terhadap produktivitas daun tiga jenis murbei di demplot kebun uji coba di Kelurahan Rurukan, Kota Tomohon, Sulawesi Utara. Penelitian ini menggunakan Rancangan Acak Lengkap dengan desain penelitian faktorial dari tiga jenis daun murbei (SULI 01, M.cathayana dan M.kanva) dengan tiga jenis pupuk (Taikam, Petroganik dan Kandang) untuk mengetahui pengaruh pemupukan. Dua jenis daun murbei (M.cathayana dan M.kanva) dengan 3 tinggi pangkasan yang berbeda $(30 \mathrm{~cm} .45 \mathrm{~cm}$ dan $60 \mathrm{~cm}$ dari permukaan tanah) untuk mengetahui pengaruh teknik pemangkasan. Sumber materi genetik murbei berasal dari Pusat Litbang Produktivitas Hutan Bogor. Parameter yang diukur meliputi pertumbuhan diameter, tinggi tanaman, dan produksi daun. Hasil penelitian menunjukkan bahwa secara umum perlakuan pemupukan tidak memberikan pengaruh terhadap produktivitas daun pada semua jenis murbei yang diuji. Aplikasi pupuk Taikam dan kandang hanya mempengaruhi pertumbuhan diameter dan tinggi tanaman murbei. Perlakuan pemangkasan tanaman memberikan pengaruh terhadap produksi daun. Bobot daun tertinggi sebesar 639,61 gram dihasilkan jenis M.kanva pada tinggi pangkasan $45 \mathrm{~cm}$, sedangkan M.cathayana menghasilkan bobot daun paling tinggi sebesar 482,40 gram pada pangkasan $60 \mathrm{~cm}$ dari permukaan tanah
\end{abstract}

Kata kunci: SULI 01, M.cathayana, M.kanva, pupuk, pertumbuhan, bobot daun

\section{PENDAHULUAN}

Persuteraan alam merupakan kegiatan agro-industri yang sudah lama dikenal dan dibudidayakan oleh masyarakat pedesaan di Indonesia, memiliki prospek inovasi yang sangat baik sebab produk dari sutera alam tidak 
saja diminati masyarakat lokal tapi juga oleh masyarakat internasional. Indonesia membutuhkan benang sutera hingga mencapai 900 ton per tahun, namun kebutuhan tersebut baru bisa dipenuhi sebesar 5\%, sedangkan $95 \%$ lainnya impor dari China (Pudjiono, Andadari, \& Darwo, 2016). Sementara itu, kualitas kokon dan benang produk sutera alam Indonesia lebih baik dibandingkan dengan produk hibrid dari China (Andadari \& Kuntadi, 2014; Pudjiono et al., 2016). Daerah-daerah yang telah mengembangkan agroindustri sutera alam yaitu Sulawesi Selatan, Jawa Barat, Jawa Tengah, Sulawesi Barat, Bali, NTT dan Sulawesi Utara. Sulawesi Selatan merupakan sentra industri persutraan terbesar (Muin \& Isnan, 2018). Sutera alam menjadi bagian penting dalam kebudayaan masyarakat Sulawesi Selatan dan sekitar $80 \%$ kebutuhan nasional di suplai dari wilayah ini (Harbi, Nurrochmat, \& Kusharto, 2015; Nuraeni, 2017). Meski demikian, produksi kokon yang dihasilkan belum cukup untuk memenuhi kebutuhan para pengusaha benang dan kain sutera secara nasional.

Kendala yang sering dihadapi dalam agroindustri sutera alam antara lain masih rendahnya produktivitas murbei sebagai satusatunya pakan ulat sutera dalam memproduksi kokon (Setiadi, Kasno, \& Haneda, 2011). Andadari dan Irianto (2011) menyatakan bahwa kuantitas dan kualitas daun murbei tidak hanya memberikan pengaruh yang signifikan terhadap pertumbuhan dan kelangsungan hidup ulat sutera namun juga menentukan mutu kokon yang dihasilkan. Andikarya (2019) menyatakan bahwa 38\% kualitas kokon dipengaruhi oleh kualitas murbei hasil budidaya. Oleh karena itu untuk meningkatkan produksi kokon dan benang sutera yang berkualitas dan mencapai target perlu dimulai dari pembangunan kebun murbei yang berkualitas pula (Ilyas, Kassa, \& Muis, 2015). Produksi daun murbei dipengaruhi oleh tempat tumbuh, pemilihan jenis, teknik pemangkasan, pemupukan, pengendalian hama dan penyakit serta penanganan ketika musim kemarau (Santoso, Wardani, \&
Prayudyaningsih, 2006). Perbedaan ketinggian tempat dan iklim mikro lokasi kebun murbei dapat menyebabkan perbedaan produktivitas daun murbei yang dihasilkan (Nurhaedah \& Bisjoe, 2013).

Upaya yang dapat dilakukan untuk meningkatkan kapasitas produksi kokon adalah dengan menambah sentra produksi di wilayah lain yang memiliki kondisi lingkungan yang sesuai untuk pertumbuhan murbei dan pemeliharaan ulat sutera. Semakin banyak wilayah yang mengembangkan industri sutera alam diharapkan dapat meningkatkan pasokan benang sutera dalam memenuhi kebutuhan nasional. Kota Tomohon di Sulawesi Utara pernah menjadi sentra pengembangan usaha sutera alam di pertengahan tahun 1990an. Namun tutupnya perusahaan Korea di Minahasa Utara yang menjadi tempat pemasaran kokon menyebabkan ketidakberlanjutan usaha tani tersebut. Balai Persuteraan Alam melaporkan bahwa pada tahun 2015 terdapat 42 kepala keluarga yang masih melakukan agro-industri sutera alam (Muin \& Isnan, 2018). Pemerintah daerah bekerjasama dengan stakeholder berupaya untuk menggiatkan kembali usaha persuteraan alam di wilayah ini. Oleh karena itu, Balai Litbang LHK Manado memandang perlu untuk membangun demplot dan menguji cobakan tiga jenis murbei (Suli, Morus cathayana dan Morus kanva). Suli merupakan hibrid yang dihasilkan oleh peneliti Pusat Litbang Produktivitas Hutan Bogor. Kandungan nutrisi pada M.cathayana memberikan ketahanan tubuh ulat sutera paling baik (Rahma, Moerfiah, \& Andadari, 2017), M.kanva memiliki ukuran helai daun cukup besar sehingga menghasilkan produktivitas daun yang tinggi (Dewi \& Hastuti, 2017) sedangkan Suli memproduksi daun dua kali lebih banyak dari M.cathayana (Pudjiono et al., 2016).

Sehubungan dengan hal tersebut maka penting untuk melakukan penelitian mengenai kemampuan tiga jenis murbei (Suli, M.cathayana dan M.kanva) dalam memproduksi daun di wilayah dataran tinggi 
Sulawesi Utara. Tujuan dari penelitian ini adalah untuk mengetahui tinggi pemangkasan dan aplikasi pupuk yang tepat agar produktivitas daun murbei optimal. Diharapkan penelitian ini akan menjadi show window bagi masyarakat, mahasiswa, pelajar praktisi dan stakeholder terkait lainnya. Dengan demikian usaha sutera alam akan tumbuh kembali dan menjadi salah satu sumber perekonomian masyarakat dimasa yang akan datang.

\section{METODE PENELITIAN}

\section{A. Lokasi}

Penelitian ini dilakukan pada demplot kebun murbei seluas 1 ha yang dibangun di Kelurahan Rurukan Satu, Kecamatan Tomohon Timur, Kota Tomohon, Provinsi Sulawesi Utara (Gambar 1). Kebun murbei berada pada wilayah dengan ketinggian antara 757-1100 meter d.p.1., suhu berkisar antara $20^{\circ} \mathrm{C}-37^{\circ} \mathrm{C}$, kelembaban rata-rata $57-89 \%$ dan curah hujan rata-rata 2.324 $\mathrm{mm} /$ tahun (BPS, 2017). Tomohon memenuhi syarat sebagai lokasi pengembangan budidaya tanaman murbei dan ulat sutera.

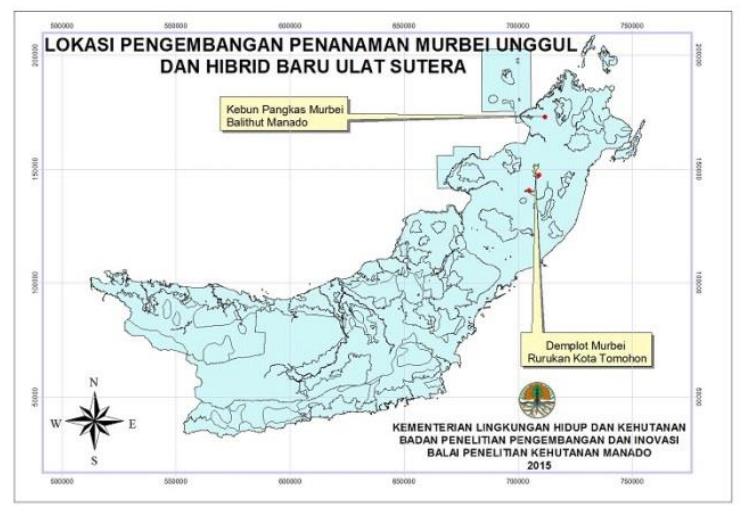

Gambar 1. Lokasi Pengembangan Murbei di Plot Pengembangan Kelurahan Rurukan, Kota Tomohon, Sulawesi Utara

\section{B. Bahan dan alat}

Alat yang digunakan pada penelitian ini yaitu tally sheet, papan data, personel use, handcounter, meteran, GPS, kamera, caliper, penggaris, timbangan digital, plastik clip, plaging tab, gunting stek, spidol dan alat tulis menulis. Bahan tanaman yang digunakan pada penelitian ini adalah tiga jenis murbei yaitu
M.cathayana, M.kanva dan murbei jenis hibrid SULI 01 (M.cathayana $x$ M.amakusaguwa IV.12) (Andadari, Minarningsih, \& Dewi, 2017), dengan jarak tanam 1 x $1 \mathrm{~cm}$. Pupuk yang digunakan terdiri dari pupuk organik jenis petroganik, taikam, dan pupuk kandang.

\section{Metode}

Penelitian ini merupakan penelitian eksperimen menggunakan rancangan acak lengkap (RAL) dengan desain penelitian faktorial dengan dua faktor pada masing-masing perlakuan sebagai berikut:

Untuk mengetahui pengaruh perlakuan pemupukan; faktor pertama adalah jenis murbei yang terdiri dari 3 taraf uji yaitu M.cathayana, M.kanva dan SULI 01. Faktor kedua adalah jenis pupuk yang terdiri dari 3 jenis pupuk (taikam, petroganik dan pupuk kandang) dan 1 kontrol. Taikam merupakan pupuk kotoran kambing yang dapat menyediakan unsur makro $(\mathrm{N}, \mathrm{P}, \mathrm{K})$ dan mikro (Ca, Mg, S, Na, Fe, Cu, Mo) yang dibutuhkan tanaman (Rihana, Heddy, \& Maghfoer, 2013), pupuk Petroganik memiliki kandungan $\mathrm{C}$ organik dan nitrogen yang tinggi (Rahmatika, 2015) dan pupuk kandang kotoran ayam mengandung unsur $\mathrm{N}$ yang sangat tinggi $(2,71 \%)$ dibandingkan pupuk kotoran hewan lainnya (Laude \& Tambing, 2010). Tiap perlakuan menggunakan ulangan sebanyak 20 tanaman, sehingga jumlah tanaman keseluruhan sebanyak 240 tanaman (3 jenis murbei x 4 perlakuan pupuk x 20 ulangan). Dosis pupuk yang diberikan pada setiap tanaman perlakuan sebanyak $1 \mathrm{~kg}$. Pengamatan pertumbuhan dilakukan setelah 7 bulan pemupukan.

Untuk mengetahui pengaruh perlakuan tinggi pemangkasan; faktor pertama adalah jenis murbei yang terdiri dari 2 taraf uji yaitu M.cathayana dan M kanva. Faktor kedua adalah tinggi pangkasan yang terdiri dari 3 taraf uji (tinggi $30 \mathrm{~cm}, 45 \mathrm{~cm}$ dan $60 \mathrm{~cm}$ ). Tiap perlakuan menggunakan ulangan sebanyak 15 tanaman, sehingga jumlah total keseluruhan tanaman sebanyak 90 tanaman. Pemangkasan pertama dilakukan pada umur tanaman 1 tahun 
sedangkan pengamatan pertumbuhan dan produktivitas daun dilakukan pada 3 bulan setelah pemangkasan. Pada perlakuan ini sampel tanaman SULI 01 tidak dilakukan pengamatan karena tanaman uji terserang hama.

Parameter yang diamati pada tanaman contoh adalah diameter, tinggi total tanaman, jumlah daun dan bobot daun. Bobot daun diketahui dengan cara menghitung seluruh jumlah daun pada tanaman contoh kemudian dikalikan dengan rata-rata bobot per helai daun. Bobot rata-rata per helai daun diketahui dengan cara menimbang sebanyak lima daun yang diambil secara acak pada setiap tanaman contoh.

\section{Analisis data}

Data hasil pengukuran dianalisis sidik ragam pada taraf kepercayaan 95\% menggunakan software SPSS 16 (Setiadi et al., 2011) untuk mengetahui pengaruh perlakuan terhadap parameter yang diamati. Jika terdapat perbedaan secara nyata dilakukan uji lanjut dengan Tukey test untuk mengetahui perbedaan masing-masing taraf uji pada tiap perlakuan (Vanadis, Suartini, \& Ariantari, 2013).

\section{HASIL DAN PEMBAHASAN}

\section{A. Pengaruh pemupukan pada tiga jenis murbei}

Demplot pengembangan murbei berada pada hamparan lahan hortikultura dengan variasi kemiringan lereng antara datar hingga agak curam. Pengukuran tanaman dilakukan untuk mengetahui kemampuan adaptasi murbei terhadap lahan hortikultura dan produktivitasnya. Parameter ini penting karena menjadi salah satu indikator penilaian terhadap keberhasilan pengembangan penanaman murbei.

Tabel 1. Hasil analisis sidik ragam perlakuan jenis pupuk pada 3 jenis murbei

\begin{tabular}{lrrrr}
\hline & \multicolumn{4}{c}{ F hitung } \\
\cline { 2 - 5 } \multicolumn{1}{c}{ Perlakuan } & Diameter & Tinggi tanaman & Jumlah daun & Bobot daun \\
\hline Jenis murbei & $31,336^{*}$ & $21,884^{*}$ & $113,363^{*}$ & $12,069^{*}$ \\
Jenis pupuk & $10,112^{*}$ & $14,068^{*}$ & $0,668^{\text {ns }}$ & $0,599^{\text {ns }}$ \\
Jenis murbei x jenis pupuk & $8,522^{*}$ & $11,777^{*}$ & $5,049^{*}$ & $8,353^{*}$ \\
\hline
\end{tabular}

Keterangan: $(*)$ beda nyata pada taraf uji $95 \% ;\left({ }^{\text {ns }}\right)$ tidak berbeda nyata

Analisis sidik ragam pada Tabel 1 menunjukkan bahwa jenis murbei memberikan pengaruh nyata terhadap pertumbuhan tanaman dan produktivitas daun. Sedangkan aplikasi jenis pupuk yang berbeda hanya memberikan pengaruh nyata terhadap pertumbuhan diameter dan tinggi tanaman. Tabel 1 juga menunjukkan bahwa terjadi interaksi antara jenis murbei dengan jenis pupuk yang digunakan terhadap parameter diameter, tinggi tanaman, jumlah daun dan bobot daun.

Uji lanjut Tukey dilakukan untuk mengetahui beda rata-rata setiap taraf uji yang menunjukkan pengaruh berbeda nyata. Hasilnya menunjukkan bahwa diameter dan bobot daun SULI 01 berbeda signifikan terhadap M.cathayana dan M.kanva, sedangkan M.cathayana dan M.kanva mempunyai diameter dan bobot daun yang tidak berbeda nyata. Tinggi tanaman dan jumlah daun ketiga jenis murbei berbeda signifikan antara satu dan lainnya. Perbedaan masing-masing parameter pada ketiga jenis murbei dapat dilihat pada Tabel 2.

Jumlah daun dan bobot daun berkorelasi positif terhadap produktivitas tanaman murbei, semakin banyak jumlah dan bobot daun maka produktivitas tanaman akan semakin tinggi (Pudjiono et al., 2016). Pada penelitian ini daun murbei SULI 01 menunjukkan produktivitas paling rendah. Hasil ini bertolak belakang dengan hasil penelitian dari (Pudjiono et al., 2016) yang menyatakan bahwa SULI 01 yang ditanam pada dataran tinggi menghasilkan produksi daun dua kali lebih banyak dibandingkan dengan produksi daun 
M.cathayana. SULI 01 mempunyai daun yang lebih lebar dan membulat dibandingkan dengan bentuk M.cathayana yang kecil dan berlekuklekuk (Rahma et al., 2017) sehingga produktivitas daunnya lebih besar. Hal ini dimungkinkan karena pada saat pengamatan banyak daun yang gugur sehingga jumlah daun pada tiap tanaman uji meranggas oleh karenanya meskipun tinggi tanaman SULI 01 lebih tinggi namun jumlah dan bobot daunnya lebih rendah.

Tabel 2. Rata-rata pertumbuhan tanaman dan produktivitas daun tiga jenis murbei

\begin{tabular}{|c|c|c|c|c|}
\hline \multirow{2}{*}{ Jenis } & \multicolumn{4}{|c|}{ Parameter } \\
\hline & Diameter $(\mathrm{cm})$ & Tinggi tanaman $(\mathrm{cm})$ & Jumlah daun (helai) & Bobot daun (gr) \\
\hline SULI 01 & $1.57^{\mathrm{a}}$ & $175.00^{\mathrm{a}}$ & $29.61^{\mathrm{a}}$ & $135.14^{\mathrm{a}}$ \\
\hline M.cathayana & $1.18^{\mathrm{b}}$ & $142.55^{\mathrm{b}}$ & $83.33^{b}$ & $223.10^{b}$ \\
\hline M.kanva & $1.16^{\mathrm{b}}$ & $118.35^{\mathrm{c}}$ & $117.66^{\mathrm{c}}$ & $278.50^{b}$ \\
\hline
\end{tabular}

Keterangan: angka yang diikuti oleh huruf yang sama menunjukkan tidak berbeda nyata pada uji Tukey

Jumlah daun dan bobot daun berkorelasi positif terhadap produktivitas tanaman murbei, semakin banyak jumlah dan bobot daun maka produktivitas tanaman akan semakin tinggi (Pudjiono et al., 2016). Pada penelitian ini daun murbei SULI 01 menunjukkan produktivitas paling rendah. Hasil ini bertolak belakang dengan hasil penelitian dari Pudjiono et al. (2016) yang menyatakan bahwa SULI 01 yang ditanam pada dataran tinggi menghasilkan produksi daun dua kali lebih banyak dibandingkan dengan produksi daun M.cathayana. SULI 01 mempunyai daun yang lebih lebar dan membulat dibandingkan dengan bentuk M.cathayana yang kecil dan berlekuklekuk (Rahma et al., 2017) sehingga produktivitas daunnya lebih besar. Hal ini dimungkinkan karena pada saat pengamatan banyak daun yang gugur sehingga jumlah daun pada tiap tanaman uji meranggas oleh karenanya meskipun tinggi tanaman SULI 01 lebih tinggi namun jumlah dan bobot daunnya lebih rendah.

Pupuk kandang yang digunakan dalam penelitian ini adalah pupuk kandang dari kotoran ayam, sedangkan pupuk taikam berasal dari kotoran kambing. Uji lanjut Tukey menunjukkan bahwa pemberian pupuk petroganik tidak memberikan pengaruh signifikan terhadap perbedaan pertumbuhan diameter dan tinggi tanaman dibandingkan dengan tanaman kontrol tanpa pemupukan. Pemberian pupuk taikam dan pupuk kandang secara signifikan meningkatkan diameter dan tinggi tanaman. Juwarman, Astiningrum, dan Suprapto (2016) menyatakan bahwa tanaman murbei membutuhkan nitrogen lebih banyak dibandingkan unsur hara lainnya. Dimana pupuk yang memiliki bahan dasar unsur makro seperti nitrogen dan sulfur dapat meningkatkan kualitas murbei (Fauziah, Prihatin, \& Suratno, 2018). Oleh karena itu pemberian pupuk kandang sangat cocok bagi pertumbuhan murbei, sebab kotoran ayam yang melapuk mengandung bahan organik ,jasad renik, nitrogen dan phosphor yang cukup tinggi (Prastya, Wahyudi, \& Baharudin, 2016; Tufaila, Laksana, \& Alam, 2014).

Tabel 3.Rata-rata pertumbuhan diameter dan tinggi tanaman pada aplikasi jenis pupuk yang berbeda

\begin{tabular}{lcc}
\hline \multirow{2}{*}{ Jenis } & \multicolumn{2}{c}{ Parameter } \\
\cline { 2 - 3 } pupuk & Diameter $(\mathrm{cm})$ & Tinggi tanaman $(\mathrm{cm})$ \\
\hline Kontrol & $1.16 \mathrm{~b}$ & $125.80 \mathrm{~b}$ \\
Taikam & $1.40 \mathrm{a}$ & $171.38 \mathrm{a}$ \\
Petroganik & $1.18 \mathrm{~b}$ & $119.70 \mathrm{~b}$ \\
Kandang & $1.47 \mathrm{a}$ & $164.32 \mathrm{a}$ \\
\hline
\end{tabular}

Keterangan: angka yang diikuti oleh huruf yang sama menunjukkan tidak berbeda nyata pada uji Tukey 
Tabel 1 menunjukkan bahwa interaksi antara jenis murbei dan jenis pupuk yang diaplikasikan memberikan pengaruh yang nyata terhadap parameter pertumbuhan diameter, tinggi, jumlah daun dan bobot daun. Respon terbaik terhadap tinggi tanaman terjadi pada murbei SULI 01 dengan tinggi mencapai 169,32 $\mathrm{cm}$ pada perlakuan pupuk kandang. Pertumbuhan diameter terbesar $(1,34 \mathrm{~cm})$ juga pada murbei SULI 01 namun pada perlakuan pupuk taikam. Pupuk taikam memberikan respon rata-rata pertumbuhan diameter dan tinggi terbaik pada murbei SULI 01 yaitu masing-masing sebesar $1,34 \mathrm{~cm}$ dan $162,16 \mathrm{~cm}$. Selain pertumbuhan tinggi tanaman, perlakuan pupuk kandang pada Murbei SULI 01 juga menunjukkan penambahan diameter kedua terbaik sebesar 1,28 cm.

Pupuk kandang berkontribusi menghasilkan produksi daun tertinggi sebesar 322,52 gram pada jenis M.kanva. Nilai bobot daun tertinggi kedua terlihat pada jenis M.cathayana pada perlakuan pupuk taikam sebesar 286,83 gram, dan untuk murbei SULI01 bobot daun tertinggi juga terjadi pada perlakuan pupuk taikam. Secara umum perlakuan pemupukan kurang memberikan pengaruh besar terhadap parameter produktivitas daun murbei. Hal ini kemungkinan karena pupuk yang diujicobakan merupakan jenis-jenis pupuk organik. Hasil ini sama dengan penelitian yang telah dilakukan departemen silvikultur Institut Pertanian Bogor dimana perlakuan pupuk organik tidak memberikan pengaruh yang nyata untuk parameter tinggi tanaman, jumlah daun, bobot daun dan panjang cabang tanaman murbei (Setiadi et al., 2011). Jumlah dan bobot daun yang dihasilkan tanaman murbei sangat berpengaruh terhadap budidaya ulat sutera, sebab jumlah produksi daun yang dihasilkan menentukan ketersediaan pakan ketika pelaksanaan budidaya ulat sutera.

\section{B. Pengaruh tinggi pemangkasan pada dua jenis murbei}

Pemangkasan dilakukan dengan tiga perlakuan berbeda yaitu pangkasan rendah, sedang dan tinggi. Pengamatan pengaruh pemangkasan hanya dilakukan pada M.cathayana dan M.kanva. Hal ini untuk mengetahui kemampuan bertumbuh kedua jenis tersebut pasca perlakuan pemangkasan terutama terhadap tunas baru dan jumlah produksi daun yang dihasilkan. Selain itu pemangkasan sangat baik bagi tanaman murbei sebab semakin sering dipangkas maka jumlah daun yang dihasilkan akan bertambah banyak. Pemangkasan bertujuan untuk merangsang munculnya tunastunas produktif yang akan meningkatkan produksi tanaman, memperbaiki kualitas daun, merapikan penampilan tanaman, menjaga kesehatan tanaman dari serangan hama dan penyakit dan memudahkan petani dalam melakukan panen (Juwarman et al., 2016).

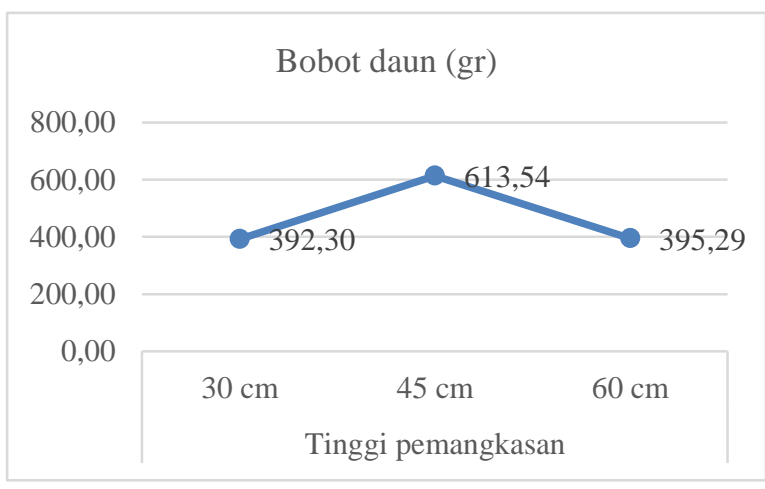

Gambar 1. Pengaruh tinggi pemangkasan terhadap bobot daun

Tabel 4. Hasil analisis sidik ragam perlakuan tinggi pemangkasan pada dua jenis murbei

\begin{tabular}{lrrrr}
\hline & \multicolumn{4}{c}{ F hitung } \\
\cline { 2 - 5 } Perlakuan & Diameter & Tinggi tanaman & Jumlah daun & \multicolumn{1}{c}{ Bobot daun } \\
\hline Jenis murbei & $12,072^{*}$ & $13,146^{*}$ & $23,561^{*}$ & $10,067^{*}$ \\
Tinggi pemangkasan & $1,273^{\text {ns }}$ & $2,339^{\text {ns }}$ & $2,546^{\text {ns }}$ & $6,768^{*}$ \\
Jenis x pemangkasan & $5,075^{*}$ & $3,952^{*}$ & $0,877^{\text {ns }}$ & $10,937^{*}$ \\
\hline
\end{tabular}

Keterangan: $(*)$ beda nyata pada taraf uji $95 \% ;\left({ }^{\text {ns }}\right)$ tidak berbeda nyata 
Analisis sidik ragam menunjukkan bahwa kedua jenis murbei memberikan pengaruh yang berbeda nyata terhadap rata-rata diameter, tinggi tanaman, jumlah daun dan bobot daun per pohon. Sedangkan tinggi pemangkasan hanya memberikan pengaruh yang nyata terhadap bobot daun. Gambar 1 menunjukkan bahwa pemangkasan dengan tinggi $45 \mathrm{~cm}$ dari permukaan tanah menghasilkan perbedaan ratarata bobot daun paling besar dibandingkan kedua teknik pemangkasan lainnya. Hal ini dimungkinkan karena pada tinggi pangkasan 30 $\mathrm{cm}$, tanaman tidak dapat tumbuh dengan optimal sebab tanaman harus bersaing dengan rumput dan gulma, dimana rumput dan gulma sangat cepat tumbuh pada lokasi demplot kebun uji coba.

Gambar 2 menunjukkan bahwa M.kanva memproduksi daun lebih tinggi dibandingkan dengan M.cathayana meskipun dengan tinggi tanaman yang lebih rendah. Hasil penelitian ini sejalan dengan yang dikemukakan oleh Hutasoit, Ginting, Sirait, dan Tarigan (2016), yang menyatakan bahwa jenis murbei tertinggi adalah M.cathayana dan M.multicaulis, namun M.kanva memproduksi daun yang lebih banyak per hektarnya.

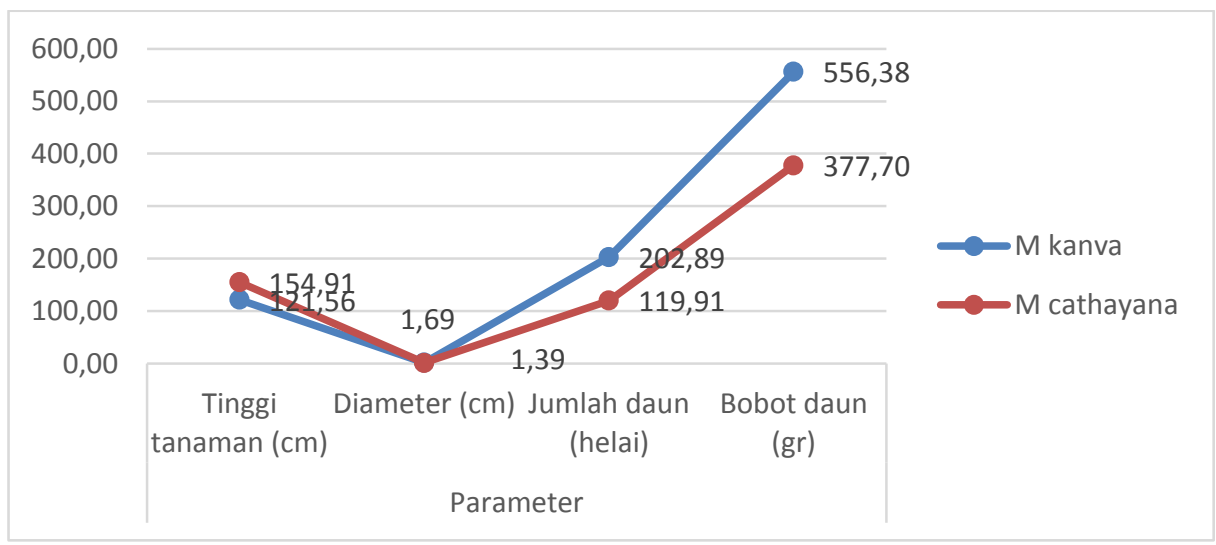

Gambar 2. Pengaruh jenis murbei terhadap pertumbuhan diameter, tinggi, jumlah dan bobot daun

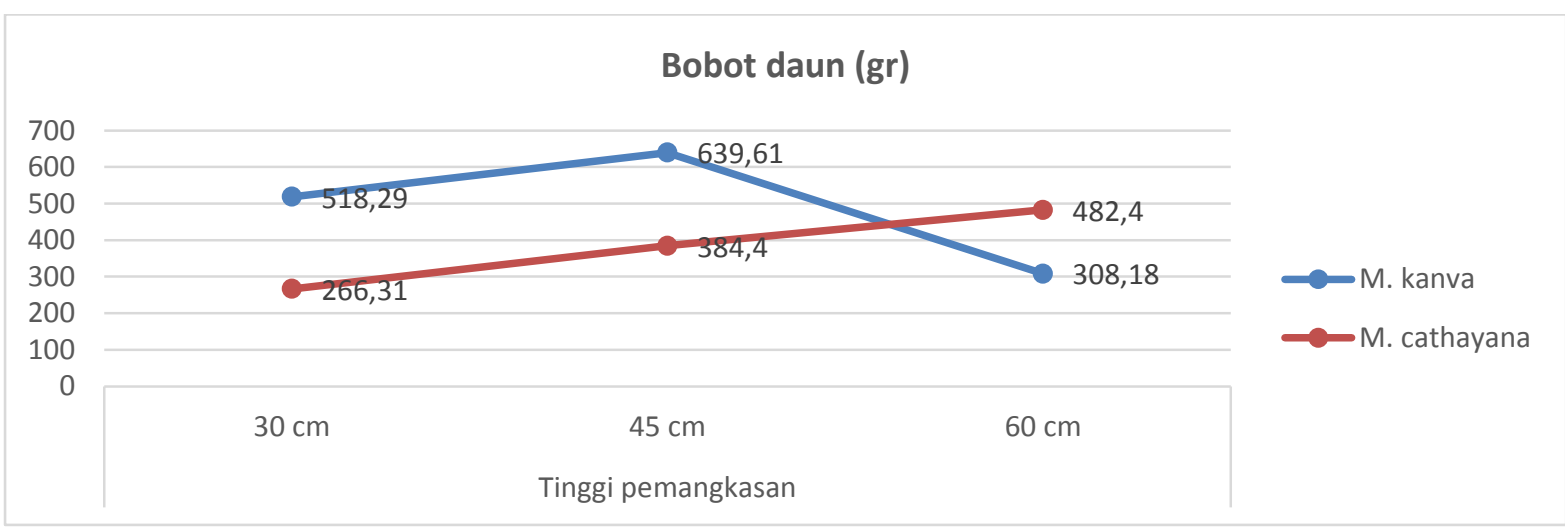

Gambar 3. Rata-rata bobot daun masing-masing jenis murbei pada tiga perlakuan tinggi pemangkasan yang berbeda

Perlakuan pemangkasan memberikan menunjukkan kecenderungan semakin pengaruh terhadap bobot daun M.kanva, semakin tinggi pangkasan justru berdampak kurang baik bagi bobot daun pada jenis ini. Sedangkan bobot daun M.cathayana meningkat dari pangaksan rendah $30 \mathrm{~cm}$ hingga pangkasan tinggi $60 \mathrm{~cm}$ (Gambar 3). M.kanva pada tinggi pangkasan $45 \mathrm{~cm}$ menghasilkan bobot daun sebesar 639,61 gram per pohon. 
Nilai ini dua kali lebih besar dari hasil yang diperolah M.cathayana dengan tinggi pangkasan yang sama. Pertumbuhan tinggi tanaman terbaik M.kanva terjadi pada tinggi pangkasan $45 \mathrm{~cm}$ dan kurang baik pada tinggi pangkasan $60 \mathrm{~cm}$. Hasil ini berbeda dengan penelitian (Juwarman et al., 2016) pada $M$. alba yang menyatakan bahwa jumlah daun dan jumlah tunas mencapai

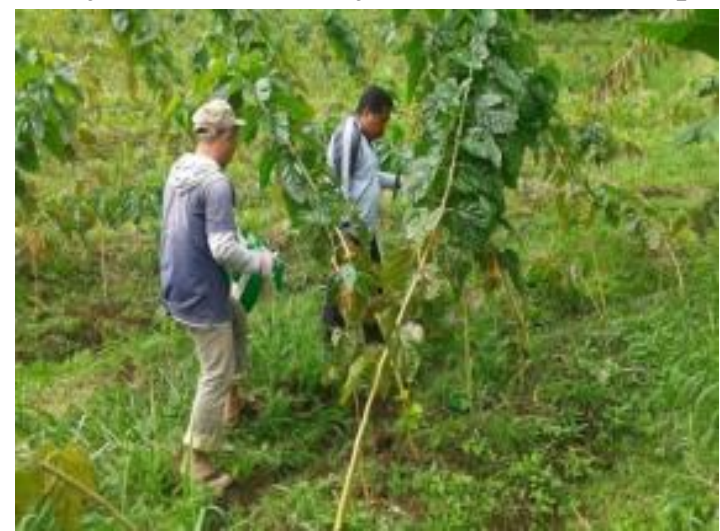

optimum pada pemangkasan 62,05 $\mathrm{cm}$. Pemangkasan digunakan untuk menjaga kestabilan tinggi tanaman murbei, merangsang munculnya tunas baru dan meningkatkan produksi daun sehingga ketersedian pakan ulat sutera terjamin (Andadari, Pudjiono, Suwandi, \& Rahmawati, 2013).

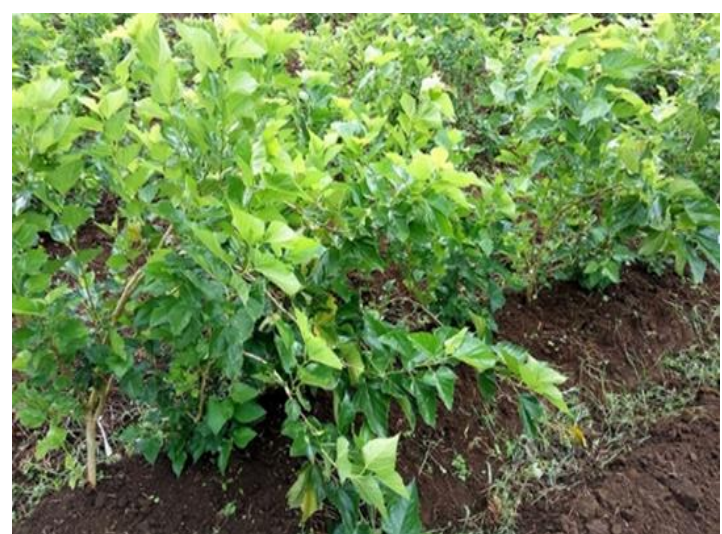

Gambar 2. Pengukuran tanaman dan kondisi tanaman setelah pemangkasan

\section{KESIMPULAN}

Secara umum aplikasi tiga jenis pupuk, yaitu taikam, petroganik dan kandang tidak memberikan pengaruh yang signifikan terhadap produktivitas daun dari tiga jenis murbei yang diuji di demplot kebun uji coba di desa Rurukan. Perlakuan tinggi pemangkasan pada dua jenis murbei hanya berpengaruh pada bobot daun per pohon, dimana bobot daun tertinggi ditemukan pada tinggi pangkasan $45 \mathrm{~cm}$ untuk jenis M.kanva, dan tinggi pangkasan $60 \mathrm{~cm}$ untuk jenis M.cathayana.

\section{UCAPAN TERIMA KASIH}

Penulis mengucapkan terima kasih kepada Balai Penelitian dan Pengembangan Lingkungan Hidup dan Kehutanan Manado yang telah mendanai kegiatan Pengembangan ini melalui Program Rencana Penelitian dan Pengembangan Integratif (RPPI) Penanaman Murbei Unggul dan Hibrid Ulat Sutera dan Pemanfaatan Limbah. Penghargaan juga kami sampaikan kepada Jafaruddin, Tajuddin Mokoginta dan Andi Baso Ikbal yang telah membantu pengambilan data di lapangan.

\section{DAFTAR PUSTAKA}

Andadari, L., \& Irianto, R. S. B. (2011). Pengaruh Pupuk Lambat Larut dan Daun Tanaman Murbei Bermikoriza Terhadap Kualitas Kokon Ulat Sutera. Jurnal Penelitian Hutan Dan Konservasi Alam, 8(2), 119-127.

Andadari, L., \& Kuntadi. (2014). Perbandingan Hibrid Ulat Sutera (Bombyx mori L.) Asal Cina dengan Hibrid Lokal di Sulawesi Selatan. Jurnal Penelitian Hutan Tanaman, 11(3), 173-183. https://doi.org/https://doi.org/10.20886/jpht.2 014.11.3.173-183

Andadari, L., Minarningsih, \& Dewi, R. (2017). Pengaruh Jenis Murbei terhadap Produktivitas Kokon Dua Hibrid Ulat Sutera Bombyx mori L. Widyariset, 3(2), 119-130.

Andadari, L., Pudjiono, S., Suwandi, \& Rahmawati, T. (2013). Budidaya Murbei dan Ulat Sutera. (M. Kaomini, N. F. Haneda, \& T. Herawati, Eds.). Bogor: FORDA PRESS.

Andikarya, R. O. (2019). Agribisnis Persuteraan Alam di Desa Pasir Sarongge Kecamatan Ciherang Kabupaten Cianjur. Composite, 1(1), 1-12.

BPS. (2017). Data Sosial Ekonomi Strategis. Data Sosial Ekonomi Strategis, (April).

Dewi, R., \& Hastuti, N. (2017). Prosiding Seminar Nasional. In Biodiversitas Untuk Kesehatan 
dan Keberlanjutan Kualitas Ekosistem (pp. 205-214).

Fauziah, R., Prihatin, J., \& Suratno, S. (2018). Pengaruh Pemberian Pupuk ZA Pada Tanaman Murbei Terhadap Kokon Ulat Sutera Alam. Bioeksperimen: Jurnal Penelitian Biologi, 4(1), 37-41. https://doi.org/10.23917/bioeksperimen.v4i1. 5929

Harbi, J., Nurrochmat, D. R., \& Kusharto, C. M. (2015). Pengembangan Usaha Persuteraan Alam Kabupaten Wajo, Sulawesi Selatan. Risalah Kebijakan Pertanian Dan Lingkungan: Rumusan Kajian Strategis Bidang Pertanian Dan Lingkungan, 2(2), 129-136. https://doi.org/10.20957/jkebijakan.v2i2.1098 3

Hutasoit, R., Ginting, S., Sirait, J., \& Tarigan, A. (2016). Productivity and Chemical Composition of Several Mulberry Species (Morus spp) Agains Spacing Plant and Cutting Age, 1(1), 50-56.

Ilyas, N., Kassa, S., \& Muis, A. (2015). Analisis Kelayakan Finansial Pada Industri Jagad Sutera di Kelurahan Kamonji Kecamatan Palu Barat Kota Palu. J. Agroland, 22(2), 163-168.

Juwarman, Astiningrum, M., \& Suprapto, A. (2016). Upaya Peningkatan Kuantitas Daun Murbei (Morus alba) Dengan Macam Pupuk Nitrogen dan Tinggi Pemangkasan. VIGOR: Jurnal Imu Pertanian Tropika Dan Subtropika, 1(1), 23-30.

Muin, N., \& Isnan, W. (2018). Kelembagaan Petani Sutera Di Kabupaten Soppeng. Info Teknis Eboni, 15(1), 41-52.

Nuraeni, S. (2017). Gaps in the thread: Disease, production, and opportunity in the failing silk industry of South Sulawesi. Forest and Society, 1(2), 110-120. https://doi.org/10.24259/fs.v1i2.1861

Nurhaedah, M., \& Bisjoe, A. R. H. (2013). Budidaya Ulat Sutera di Desa Sudu, Kecamatan Alla, Kabupaten Enrekang, Sulawesi Selatan. Jurnal Penelitian Hutan Tanaman, 10(4), 229-239.

https://doi.org/https://doi.org/10.20886/jpht.2 013.10.4.229-239

Prastya, D., Wahyudi, \& Baharudin. (2016). Pengaruh Jenis dan Komposisi Pupuk Kandang Ayam dan Pupuk NPK terhadap Serapan Nitrogen dan Hasil Bawang Merah
(Allium ascalonicum L.) Varietas Lembah Palu di Entisol Sidera. E-J Agrotekbis, 4(4), 384-393.

Pudjiono, S., Andadari, L., \& Darwo. (2016). Pemilihan Jenis Hibrid Murbei Untuk Dikembangkan Di Dataran Tinggi. Jurnal Penelitian Hutan Tanaman, 13(2), 133-138. https://doi.org/https://doi.org/10.20886/jpht.2 016.13.2.133-138

Rahma, F., Moerfiah, \& Andadari, L. (2017). Pertumbuhan dan Kualitas Kokon Ulat Sutera (Bombyx mori) dengan Pemberian Pakan Daun Murbei (Morus catayana) dan Daun Murbei Hibrid Suli-01. Jurnal Online Mahasiswa Bidang Biologi, 3(3), 1-9.

Rahmatika, W. (2015). Respon Macam Varietas Tanaman Jagung (Zea mays L.) Terhadap Beberapa Dosis Pupuk Petroganik. Jurnal Cendekia, 13(2), 1-6.

Rihana, S., Heddy, Y. B. S., \& Maghfoer, M. D. (2013). Pertumbuhan dan Hasil Tanaman Buncis (Phaseolus vulgaris L.) Pada Berbagai Dosis Pupuk Kotoran Kambing dan Konsentrasi Zat Pengatur Tumbuh Dekamon. Jurnal Produksi Tanaman, 1(4), 369-377.

Santoso, B., Wardani, B. W., \& Prayudyaningsih, R. (2006). Efektivitas Pemupukan Urea Terhadap Pertumbuhan, Produksi Daun, dan Kandungan Protein Daun Murbei (Morus sp. Var NI dan Morus sp. Var. Asl). Jurnal Penelitian Hutan Dan Konservasi Alam, 3(1), $1-8$. https://doi.org/https://doi.org/10.20886/jphka. 2006.3.1.1-8

Setiadi, W., Kasno, \& Haneda, N. F. (2011). Penggunaan Pupuk Organik untuk Peningkatan Produktivitas Daun Murbei (Morus sp.) Sebagai Pakan Ulat Sutera (Bombyx mori L.). Jurnal Silvikultur Tropika, 2(3), 165-170.

Tufaila, M., Laksana, D. D., \& Alam, S. (2014). Aplikasi Kompos Kotoran Ayam Untuk Meningkatkan Hasil Tanaman Mentimun ( Cucumis sativus L .) Di Tanah Masam Application of Chicken Manure Compost to Improve Yield of Cucumber Plant (Cucumis sativus L .) In Acid Soils. Agroteknos, 4(2), 120-127.

Vanadis, P. A., Suartini, N. M., \& Ariantari, N. P. (2013). Analisis Antimalaria Ekstrak Metanol Daun Murbei (Morus alba) pada Mencit Terinfeksi. Jurnal Farmasi Udayana, 2(1), 45-51. 
Jurnal Pemuliaan Tanaman Hutan

Vol. 13 No. 2, Desember 2019, p. 95 - 103 